\title{
Review of Design and Build Construction: Descriptive Statistics in one of the South East Asia country
}

\author{
Raymond Yip Hock Seng1, Herman Shah Anuar2 \\ 1Othman Yeop Abdullah Graduate School of Business, Universiti Utara Malaysia, Malaysia \\ Email: raykayip@ hotmail.com \\ ${ }_{2}$ Othman Yeop Abdullah Graduate School of Business, Universiti Utara Malaysia, Malaysia \\ Email: herman@uum.edu.my \\ 1Corresponding author: raykayip@hotmail.com
}

Received: January 142020 Revised: June 22020 Accepted: June 72020 Published: June 30 2020

\begin{abstract}
In the area of the construction sector, the primary concern is economic growth. There are many issues and challenges associated with it. The growth and rapid development of this industry put their players, mainly the construction firms feeling the heat by competing with each other. The main challenge is the completion period for a particular project. This study was done in Manila, Philippines, where Design and Build (D\&B) method has gained much interest and considered very important today. The rise of new innovative systems saw the emergence of new factors in the construction industry that will become future adoption. This study focuses on factors affecting the successful completion period of the construction industry, whereby it is very crucial for the country's economic and market development. A quantitative research methodology was applied in this study. A total of 967 survey questionnaires sent out, and only 396 respondents fit to be analysed. Respondents involved were contractors, consultants, and developers. It was learned that critical success factors in project management play significant roles in driving projects to examine the determinants of success completion time of Design \& Build construction projects. Findings from this study shall be used by the authority in drafting a policy guideline for future construction development. It is hoped that this study provides a better understanding of construction challenges for future undertaking.
\end{abstract}

Keywords: Construction, design and build, factors affecting, success completion period 
Global Business Management Review, 2020

JUNE 2020

http://gbmr.oyagsb.uum.edu.my

\subsection{INTRODUCTION}

Construction industry unlike any other industries, has been slow to adopt new technologies, and has certainly never undergone a major transformation. As a result, productivity has stagnated over the last 40 years, or in some cases, even declined. Serious efforts need to be injected in order to make the industry becomes more efficient and effective in delivering the output. This uninspiring record need to be rejuvenated by providing new approaches. Undeniably, some changes has taken place in various aspects of the construction industry. It is important to note that this industry may relate well with famous phrase by William Gibson who stated that "The future is here today, it is not evenly distributed".

With the current trend today, the buzz word is digitalization. Construction industry is not by far away from it, the impact is there, so, the needs for change is a must. Transformation is being done aggressively looking at how construction companies embedded systems of digital sensors, intelligent machines, mobile devices, and new software applications. Now the famously applied are the integration with a central platform of Building Information Modelling (BIM).

Interesting findings from China, due to the recent pandemic covid-19 outbreak, they managed to build a huge hospital with just seven days. China government capitalise hundreds of heavy vehicles and armies to work day and night to build a six-acre, 1,000-bed coronavirus hospital from scratch.

This medical centre is named as Huoshenshan or Fire God Mountain Hospital, located in the suburban of Wuhan. This emergency facility was built by a strategic collaboration of four construction companies to toil through the Chinese New Year holiday for building the medical centre, which was expected to receive its first patients on February 3, 2020 (Mail Online, March 26 2020).

Therefore, there is a high time to look into the possibility of encouraging construction industry to move as fast as they can. Although there are lots of challenges ahead, no to forget, there are always room for improvement to keep the industry grow. In the case of 
Global Business Management Review, 2020

JUNE 2020

http://gbmr.oyagsb.uum.edu.my

The Global Construction Market 2012 - 2017 report shows the increased growth rate of construction projects over the five year period across the world. The growth of this sector in the Asian region seems to be the most significant, plausibly due to high demand and supply among the consumer and the service sector. The growth of the Asian economy has driven the opportunity for the emergence of new construction projects, primarily in healthcare, education and social infrastructure, as well as retail and other consumer end-markets.

This study is important in providing the new insight of current trend in construction industry. Construction is unique industry where it consolidates a lot complexity from the supplier, retailer, contractor, architect, engineer and finally to the end product. Advantage of using D\&B method procurement system is the integrated delivery system from the design to the delivery process.

The complexity inherent in construction projects in the Philippines could make way for the integration of a D\&B method by the industry. The D\&B method offers shareholders efficiency, cost saving, innovation in design and rapid completion of projects when properly applied. The outcome of this research could contractors and clients to implement a more efficient way to procure and deliver construction work using the D\&B method.

According to Triguero (2018), when the Philippines government introduce the "Build Build Build" (BBB) program, the prospects of growth in the construction sector continued to be optimistic. Government allocated huge sum of money which close to P8.1 trillion. That initiative also have a constraint in making sure that the grand plan could be materialised. For construction industry, funding is one of the major obstacle where few payment methods come into place. In the bigger scheme of the program, the government has already revised the tax system, urged more investments and secured debt financing to raise funds (The Manila Times, 2018).

Studies by Obafemi \& Roy, (2013) and Sebastiano, (2014) mentioned that improving the collaboration and interaction practices between the obstacles related to D\&B method would lead to improved resource management (including logistics, procurement and project management) and better control of the project cost and schedule. 
Global Business Management Review, 2020

JUNE 2020

http://gbmr.oyagsb.uum.edu.my

In general, construction projects can be classified into residential projects such as villa, housing developments, office buildings, hotel, factory, and warehousing and non-residential projects such as large and small commercial buildings including stores, churches, schools and hospitals and engineering projects such as bridges, roads, and reservoirs (Radhia \& Bouzid, 2017).

Regardless of the type of projects, construction projects are often characterised with a large investment, project duration, and extensive resource deployment. Due to such characterisation, the success of construction projects is essential. Multiple definitions have been presented on how project success should be defined (Williams, 2016). Historically, most scholars defined a construction project's success in terms of on-time delivery, adherence to a specified budget, and meeting client's expectation (Atkinson, 1999; Ahadzie et al., 2008).

\subsection{LITERATURE REVIEW}

Construction in the Philippines grows at a steady state when the number of approved building permits. According to the Philippine Statistics Authority (PSA), the number of approved building permits increased by $8.0 \%$ in comparison from second quarter of 2018 to second quarter 2019 (Philippine Statistics Authority, PSA, 2020).

Increment can be seen in terms the growth of residential and non-residential of $10.4 \%$ and $5.4 \%$ respectively for the same period. This indicates that the demand for the construction is on a steady growth. While the rise in construction activity indicates improvements in the industry, impact on material and labour prices are also concern of the industry players.

In the Philippines, it's important to note that residential sales are higher as compared to the the high-end market and foreigners (Philippine Statistics Authority, PSA, 2020), as they are more inclined to leasing and renting property. This will support residential construction activity in the country over the forecast period. Therefore, understanding of the demand for D\&D is crucial from the perspective of developer and client over there.

Design and build is define as a condition when a procurement route in which the main contractor is appointed to design and construct the works. In contrast with traditional contract, the client 
Global Business Management Review, 2020

JUNE 2020

http://gbmr.oyagsb.uum.edu.my

appoints consultants to design the desired project development, which later on, a contractor is appointed to construct the works to be done.

In this case, for all the employer's requirements, the person who is responsible for carrying out the duties is the contractor who needs to make sure for the design, planning, organization, control, and construction of the project. The employer will then provide tenderers the 'Employer's Requirements, and the contractors respond with the 'Contractor's Proposals', which include the price for the works to be done.

From one perspective, Design and Build (D\&B) can be seen as giving a single point of responsibility for delivering the entire project. Some clients, however, consider it is only appropriate for simple projects, where design quality is not the main consideration.

Design \& Build often been blamed for its inability to meet the client's requirement for example, when it comes to the ability to cater to changing clients' needs (Rwelamila \& Edries, 2007). With the demand and complexity of technical, economic, and multi-organizational participation, to suit the changes is also another challenge (Mohsini et al., 1995). Therefore, this problem requires a wide variety of procurement methods in order to overcome it (Love et al., 2012), by a few strategies such as Design and Build, Management Contracting, Construction Management, Project Finance Initiative and Partnering (Ghadamsi, 2016).

Mohsini et al., (1995), found that innovative procurement strategies often produce a counter effect, because they distraught the customary dependence on old-fashioned knowledge about roles and practices. Nonetheless, current studies go so far as to suggest that "integrated design," that increases the involvement of clients in the process, encourages pre-planning of design, and enables team members to share knowledge for continuous learning (Leoto et al., 2014).

\section{Advantages and Disadvantages of D\&B}

There are reasons why D\&B becomes the most popular choice among contractors. The advantages of applying D\&B includes a single point of responsibility for design and construction (Friedlander \& Roberts, 1997), quick project commencement (Ghadamsi, 2016), early price certainty 
Global Business Management Review, 2020

JUNE 2020

http://gbmr.oyagsb.uum.edu.my

(Oyegoke, et al., 2009), and benefit of contractor's experience harnessed during design (Muriro, 2015).

While pointing the advantages of $\mathrm{D} \& \mathrm{~B}$, it also has its own weaknesses including client may find it hard to prepare a sufficiently comprehensive brief, the client has to commit to a concept design early (Kotsopoulus, 2008), variations from the original brief can be difficult to arrange and expensive (Oyegoke, et al., 2009), harder to compare tenders and determine if they offer value for money and ease of fabrication may be prioritized above aesthetic quality (Muriro, 2015).

\subsection{Problem Statement}

In line with the growth and contribution of the construction sector to the Philippines economy, the prominence of the Design and Build (D\&B) method of construction approach has also gained importance. The rise of new innovative systems saw the emergence of new procurement systems in the construction industry over the past decades. The prominence of the Design and Build method has become the most common project delivery system used in many countries such as the USA, UK, Australia, and Singapore (Ling \& Kerh, 2004).

The D\&B method procurement system entails an agreement between a single entity to undertake both the design and construction of a project under one contract. The customer will deal with one entity responsible for the design to delivery of the completed project. The D\&B method procurement system has some advantages compared to other methods, including the transfer of risk to contractor, competitive design output, availability of construction expertise for design, an early commitment to maximum price, and less construction information required from the client (Ling \& Kerh, 2004).

As pointed much earlier, the success of typical construction projects is assessed based on the delivery time, the cost structure, and the quality of the project being delivered (Skitmore \& Marsden, 1998). However, the relevance of the procurement system chosen by the construction firm has been stated as a core reason for the poor performance of this industry (Masterman, 1992).

The most common method of procurement which has been used in the industry throughout the world extensively for many years is the DB method Ghadamsi, 2016, Minchin et al., 2013; Turina 
Global Business Management Review, 2020

JUNE 2020

http://gbmr.oyagsb.uum.edu.my

et al., 2008; Seng \& Yusof, 2006). For contractors, DB method is the most chosen project delivery method in the construction industry (Minchin et al., 2013). The reason DB is the preferable method is due to its time, and cost-saving reputation reduced conflicts and enhanced communication between project participants (Ghadamsi, 2016, Minchin et al., 2013).

Unique element in DB method when it applies integration from various parties from client, contractor, supplier and many more. Client provides their requirement and needs for specific project, later on contract been signed by only one organization, which is the contractor (Ghadamsi, 2016, Seng \& Yusof, 2006). Erikson \& Westerberg (2011) argued that the use of D\&B method procurement system to project's failure, mainly due to the complexity of modern construction projects that faces numerous uncertainties and the dynamics in customers' demands. Jaweed, (2004) and Kharashi \& Skitmore, (2009) highlighted the avoidance of the D\&B method as the preferred option for procuring projects in the Middle East.

Behnam (2014) reviewed the effectiveness of the D\&B method procurement system in the context of the Philippines. In a practical context, most of the D\&B method in the Philippines is done for erecting new properties and/or renovation of existing structures, thus entailing projects with varying sizes. The challenges inherent within a D\&B method construction are aplenty.

Abdul \& Olanrewaju, (2015) mentioned that in Malaysia construction project, the major issues are on the shortage of labor, delivery, costing, management, and disagreement between clients, consultants, and contractors on the use of a single system of measurement for each party's progress was among the main causes for delays. The void in academic research motivated the current research.

This article explores the reasons why D\&B method will become future adopted in the Philippines construction industry and in Manila, in specific. Such an investigation is deemed necessary for the following reasons. It aims to examine the significance of several factors to successful project management of the design \& build method among construction companies. The research will investigate the role of the targeted factors toward one of the primary elements of a project's success that is project success completion time. 
Global Business Management Review, 2020

JUNE 2020

http://gbmr.oyagsb.uum.edu.my

Since the D\&B method is comprised of an integrated approach, the elements of procurement system, currency costing, logistics delivery, and causes of delays form part of the D\&B method project management system. Thus, the research will examine these elements' role in achieving the successful completion time of construction projects in Manila, the Philippines.

The scope of this study covers the construction companies in the Philippines, which registered with the PCAB under Grade AAAA (Grade AAAA contractors are the largest contractors based on the size of the company). The scope covers residential condominiums and housing, hotel, factory, and office building in the Philippines. The study focuses on the role and association of four elements within project management of a D\&B method that is procurement system, currency costing, logistics delivery, and causes of delay. Finally, the study is characterised by the quantitative research approach.

\subsection{RESEARCH METHODOLOGY}

This study applies the survey method for collecting data. The survey questions were distributed to the contractors, consultants, and developers. These are the main player in the construction industry. Those companies that participated in the survey are registered with The Philippine Contractors Accreditation Board (PCAB) Licensed Contractor. Unit analysis for the study were companies with key managerial position, senior managements or executives, or any executivelevel officer who deals with construction projects.

This study employs non-probability sampling. The population of the construction firms in Manila, in the Philippines, are 9,670 as of 2017. Purposive and convenience sampling techniques were applied. Questionnaire being distributed through construction networks in The Philippines.

Confidence level 95\%, confidence level 5\%, population 9670, so, the sample size needed is 370 (https://surveysystem.com/sscalc.htm, 2018).

The questionnaire was designed with six sections. Section A comprised the profile of the respondents with 10 demographic questions. These questions were designed with an ordinal scale. 
Global Business Management Review, 2020

JUNE 2020

http://gbmr.oyagsb.uum.edu.my

Sections B to F comprised of Likert scale questions, with Strongly Disagree (1) through Strongly Agree (5) measures. Section B probed on the procurement system issues related to design \& build construction projects, with five (5) sub-scales and comprised of a total of 22 question.

Section $\mathrm{C}$ entailed the issue of currency costing of design \& build construction projects, with three (3) sub-scales with a total of 19 questions. Section D probed on the logistics delivery of design \& build construction projects, with a total of 20 questions in five (5) sub-scales. Section E had 23 questions pertaining to success completion time design $\&$ build construction projects, with three (3) sub-scales and Section F probed on the causes of delay of design \& build construction projects, with 14 questions in one (1) sub-scales. Questions in Sections B, C, D, and F reflect the independent variables (IVs), while Section E informs on the dependent variable (DV).

A package of the questionnaire, comprising of the questionnaire, an introductory letter, and a selfaddressed return envelope (addressed in Manila) was posted to the potential participants of 967 construction firms in Manila on June 4 2018. A follow-up email was done two weeks after sending the package. Depending on the response level, a second follow up reminder email was done by the end of June 2018. By the 1st week of July 2018, the questionnaire is no longer being collected. Only one month is being allocated to collect all the survey responses. All the questionnaires were posted to the researcher's given local address in Manila with a representative to take care of the collection.

\subsection{ANALYSIS AND FINDINGS}

The descriptive analysis in this study was conducted using the frequency distribution analysis on the demographic elements of the respondents. The demographic elements are:

\begin{tabular}{lrr}
\hline & Frequency & Percent \\
\hline Gender & & \\
Male & 286 & 72.2 \\
Female & 110 & 27.8 \\
Total & 396 & 100.0 \\
Age Group & & \\
20-35 years old & 80 & 20.2 \\
$36-50$ years old & 268 & 67.7 \\
$>51$ years old & 48 & 12.1 \\
Total & 396 & 100.0 \\
Nationality & &
\end{tabular}


Global Business Management Review, 2020

JUNE 2020

http://gbmr.oyagsb.uum.edu.my

Expatriate

Citizen

97.7

Total

100.0

Education Level

PhD

Master's Degree

0.5

Diploma

Certificate

Bachelor's

Total

13.9

Company lifetime

$<5$ years

6.1

6-10 years

34.1

$>10$ years

59.8

Total

100.0

Role in the Company

Executive

31.8

Managerial

48.0

Non-executive

2.5

Senior management

17.7

Total

100.0

Experience in the Company

$<1$ year

1-3 years

9.6

$>3$ years

41.9

Total

48.5

100.0

Number of employees in the Company

$<50$ employees

51-100 employees

11.1

51.3

$>100$ employees

37.6

Total

Average gross revenue/year (in USD million)

$<$ USD 5

USD 5-8

USD 8-11

USD $>11$

Total

Type of projects undertaken

Residential condominiums; Residential houses; Hotels

Residential condominiums; Residential houses

Office building; Residential condominiums; Residential

houses; Hotels

Office building; Residential condominiums; Residential

houses

Office building; Hotels, Office building; Factories;

Residential condominiums; Residential houses; Hotels

Office building; Factories;

Residential condominiums; Residential houses

Office building; Factories; Hotels

Office building; Factories 
Global Business Management Review, 2020

JUNE 2020

http://gbmr.oyagsb.uum.edu.my

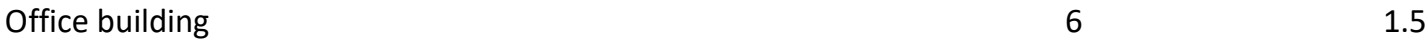

Hotels

0.5

Factories

13.9

Total

396

100.0

Table 4.1: Descriptive Statistics

\subsection{Gender}

The gender from Table 4.1 informed us that 72.2 percent of the respondents were male $(n=286)$, while the balance of 27.8 percent $(n=110)$ of them were female participants. There seem to be more male construction project operators than females in Manila. This industry is still dominant among males as compared to females.

\subsection{Age}

The analysis reveals that the majority of the respondents $(67.7$ percent, $n=268)$ were from the age category of 36-50 years old as represented in Table 4.1. Another 20.2 percent $(n=80)$ of them belonged to the age cohort of 20-35 years old. Only 12.1 percent of the respondents $(n=48)$ was 51 years and above. This indicates that the respondents were the middle 30's to early 50's adults, representing a Generation X distribution primarily.

\subsection{Nationality}

As shown in Table 4.1, nearly 97.7 percent $(n=387)$ of the respondents were citizens of the Philippines, with a remaining of 2.3 percent $(n=9)$ being an expatriate. This reflects that the results of the analysis can be generalized to the geographic location where the study was conducted.

\subsection{Education Level}

As for the Education Level in Table 4.1, most of the respondents (61.4 percent, $\mathrm{n}=243)$ are bachelor's degree holders, followed by diploma qualifiers (24.0 percent, $n=95)$. Another 13.9 percent of them are postgraduate degree holders $(n=55)$. This suggests that the respondents' answers for the sought questions can be regarded as valuable and of decent validity due to the educational background of workers. The education level of the construction industry players will determine how far the industry can grow from time to time. More and more knowledgeable and educated employees relatively will bring more improvement to the industry. 
Global Business Management Review, 2020

JUNE 2020

http://gbmr.oyagsb.uum.edu.my

\subsection{Years working in the company}

For the element of the sample company's lifetime, nearly 59.8 percent of the respondents indicated working in a company that has more than 10 years $(n=237)$ of experience in the building and construction industry (refer to Figure 4.6). This is followed by another 34.1 percent $(n=135)$ of the companies with 5-10 years of experience in the industry. A small percentage of the companies (6.1 percent, $n=24$ ) indicated being in the industry for less than 5 years. This result infers selection of stable and sound sample companies for the purpose of this study, suggesting in-depth knowledge of the local construction industry.

\subsection{Role of the Employee in the company}

The role of the responding persons in the company is crucial to be evaluated. As shown in Table 4.1, the majority (48 percent, $\mathrm{n}=190$ ) of the respondents are working in a managerial role. Another 31.8 percent $(n=126)$ of them are in executive roles. Nearly 17.7 percent $(n=70)$ of the employees are in senior managerial roles, with another 2.5 percent of them being in non-executive roles $(\mathrm{n}=$ 10). There is a sound distribution of the respondents' role and work experience in the industry, suggesting the viability of obtaining a reasonable answer to sought questions.

\subsection{Years of Experience of the Employee in the Company}

Table 4.1 indicated that most of the respondents indicated being in the company for more than 3 years (48.5 percent, $n=192$ ). This is followed closely by those working between $1-3$ years (41.9 percent, $n=166)$, and those working less than one year (9.6 percent, $n=38)$. Again, the expected answers from the ensuing survey were expected to be satisfactory as the respondents were young adults, with the probability of financial commitment. 
Global Business Management Review, 2020

JUNE 2020

http://gbmr.oyagsb.uum.edu.my

\subsection{Number of Employee Working in the Company}

In terms of the number of employees working in the company, a large proportion of the sample companies (51.3 percent, $\mathrm{n}=203$ ) suggested the existence of 51-100 employees. Nearly 37.6 percent $(n=149)$ of them have staff capable of more than 100 employees.

\subsection{Average Gross Revenue of the Company (in USD millions)}

The majority of the firms (37.4 percent, $n=148)$ indicated an average annual gross revenue of 8 11 million. Another 34.3 percent $(n=136)$ of the companies demonstrated a gross revenue of more than 11 million. Further, nearly 21.7 percent $(n=86)$ of the companies indicated earning a gross revenue of 5-8 million. Nearly 6.6 percent of the companies identified themselves with less than 5 million average annual gross revenue.

\subsection{Type of Projects Undertaken by the company}

Apart from the above-discussed elements, the survey also examined the type of projects in which the participating companies are usually involved. The type of construction projects was divided into the following categories:

\section{Office building 2. Factories 3. Residential condominiums 4. Residential houses 5. Hotels}

The result shows that most of the companies have been undertaking mixed projects. The majority of the respondents ( 23 percent, $n=91$ ) are involved in office and factory construction projects. Another 18.9 percent $(n=75)$ indicated doing a mix of residential condominiums, houses, and hotels. Another 15.2 percent $(n=60)$ firms are involved in condominiums and houses only. The third-largest cohort (12.9 percent, $\mathrm{n}=51$ ) are into the office building, condominiums, houses, and hotel constructions. On an individual perspective, most of the respondents highlighted doing only factories (13.9 percent, $\mathrm{n}=55)$.

\subsection{CONCLUSION AND RECOMMENDATION}

According to the results from the descriptive statistics, it indicates that the Construction Industry in the Philippines is continuously growing. Despite challenges here and there, this industry still gains much interest from all its main players. It can be seen that males still dominate this industry. 
Global Business Management Review, 2020

JUNE 2020

http://gbmr.oyagsb.uum.edu.my

Maybe due to its nature, this industry require a young, strong, brave, and energetic man to handle the routine work.

$87.9 \%$ are the major workforce from the age range between 20-50 years old. As we can understand, this industry requires a lot of energy, and those young people are those categories that do such a hard and dangerous job. $97.7 \%$ of respondents are local people meaning, this industry is dominated by its own citizen. This clearly indicated the construction industry provides employment to local people.

Education level remains as one of the criteria for us to see the sustainability of the industry. $75.3 \%$ are degree holders meaning that this industry is full of the talented and knowledgeable workforce. This highlighted that the industry has a future to grow better. The construction industry in the Philippines has a future because they have people with at least 5 or more years' experience working. The experience gave full advantage to the efficient and efficiency of work done by the employee.

$97.5 \%$ of respondents hold managerial level, senior manager, and executive-level participated in the study. The study findings being represented by people who have full authority of the business operation in the construction industry. Respondent holds an important position in the company which indicates that this study is very reliable. In terms of loyalty to the organization, $90.4 \%$ of respondents have work more than 1 year in the company. When the employee loyal to the company, this is where the company can become more effective and efficient in delivering their productivity.

93.4\% of respondents are companies whose revenue in the category of Average Gross Revenue USD 5 million or more. Companies involved are in the category of performing companies, and they are big companies. The majority of respondents actively build office, factory, residential, which accumulates up to $86.1 \%$ construction project. Only $13.9 \%$ focuses on constructing factories alone. Therefore, the future is bright for the construction industry to grow despite all the challenges with regards to the issue with Design and Build (DB). Future studies may look into the challenges of DB in other parts of the world. 
Global Business Management Review, 2020

JUNE 2020

http://gbmr.oyagsb.uum.edu.my

\subsection{REFERENCES}

Ahadzie, D.K., Proverbs, D.G. \& Olomolaiye, P.O. (2008). Critical Success Criteria for Mass House Building Projects in Developing Countries. International Journal of Project Management, 26(6), 675-687.

Atkinson, R. (1999). Project Management: Cost, Time, and Quality, Its Time to Accept other Success Criteria. International Journal of Project Management, 17(6), 337-342.

Eriksson, P.E., \& Westerberg, M. (2011). Effects of cooperative procurement procedures on construction project performance: A conceptual framework, International Journal of Project Management, 29, (2), 197-208.

Friedlander, M.C., \& Roberts, K.M. (1997). Design-Build-The Single Entity Option, Independent Energy, 1-5.

https://www.schiffhardin.com/Templates/media/files/publications/PDF/single_entity_desig n_build.pdf

Ghamdamsi, A. (2016). Criteria for Selection of Design and Build Procurement Method, Journal of Construction Management, 1-19.

Kharashi, A.A., \& Skitmore, M. (2009). Causes of delays in Saudi Arabian public sector construction projects, Construction Management and Economics, 27 (1), 3-23.

Ling, F.Y. \& Kerh, S.H. (2004). Comparing the Performance of Design \& Build and Design-BidBuild Building Projects in Singapore. Architectural Science Review, 47, 163-176.

Love, P., Edwards, D., Irani, Z., \& Sharif, A. (2012). Participatory Action Research Approach to Public Sector Procurement Selection. Journal of Construction Engineering Management, $138(3), 311-322$. 
Global Business Management Review, 2020

JUNE 2020

http://gbmr.oyagsb.uum.edu.my

Mohsini, R., Sirpal, R. \& Davidson, C. (1995). Procurement: A comparative analysis of construction management and traditional building processes. Building Research and Information, 23,285-290. DOI: 10.1080/09613219508727477.

Muriro, A. (2015). Design and Build Procurement Method In Practice: Key Challenges And Practice Based Enablers, Theses for the Degree of Professional Doctorate in Construction Management, July 2015, 1-494.

Masterman, J.W.E. (1992). An Introduction to Building Procurement Systems. Spon.

Minchin, R., Jr., Li, X., Issa, R., \& Vargas, G. (2013). Comparison of Cost and Time Performance of DesignBuild and Design-Bid-Build Delivery Systems in Florida. Journal Construction Engineering Management, 139(10), 04013007

Olanrewaju, A.L., \& Abdul-Aziz, A.R. (2015). An overview of the construction industry, Building Maintenance Processes and Practices, 9-32.

Oyegoke, A.S., Dickson, M., McDermott, P., Khalfan, M., \& Rowlinson, S. (2009). Construction project procurement routes: An in-depth critique, International Journal of Managing Projects in Business, 2(3), 338-354, retrieved on January 29, from file://C:/Users/USER/Downloads/Constructionprojectprocurementroutes_anindepthcritique2009.pdf

Radhia, A. \& Bouzid, A. (2017). Transport Infrastructure and Economic Growth. Journal of Infrastructure Development, 9(2).

Rwelamila, P.D., \& Edries, R. (2007). Project procurement competence and knowledge base of civil engineering consultants: An empirical study, Journal of Management in Engineering, 23(4), 182-192.

Seng, N. W., \& Yusof, A. M. (2006). The success factors of design and build procurement method: a literature visit, Proceedings of the 6th Asia-Pacific Structural Engineering and Construction Conference, 1-11. 
Global Business Management Review, 2020

JUNE 2020

http://gbmr.oyagsb.uum.edu.my

Skitmore, R. M., \& Marsden, D. E. (1988). Which procurement system? Towards a universal procurement selection technique, Construction Management and Economics, 6 (1), 71-89.

The survey system, (2018). https://surveysystem.com/sscalc.htm, 2018.

Shamas-Ur-R. T., \& Ogunlana, S.O. (2008) Problems causing delays in major construction projects in Thailand, Construction Management and Economics, 26 (4), 395408, DOI: 10.1080/01446190801905406

Triguero, R. (2018). Funding today's construction industry, The Manila Times, August 4, 2018, retrieved on April 28, from https://www.manilatimes.net/2018/08/04/business/columnistsbusiness/funding-todays-construction-industry/426433/

Turina, N., Radujkovic. M., \& Pusic, D. C. (2008). Design and build in comparison with the traditional procurement and possibility of its application in the Croatian construction industry, 8th International Conference: Organization, Technology and Management in Construction, 17th -20th of September 2008 Umag, Hrvatska, Available at: http://bib.irb.hr/datoteka/362416.65-Turina_RadujkovicCarPusic.pdf (Accessed: April 2 2011).

Williams, T. (2016). Identifying Success Factors in Construction Projects: A case study of Project Management Journal, 41, 97-112.

Yildiz, A.E., Dikmen, I., Birgonul, M.T., Ercoskun, K. \& Alten, S. (2014). A Knowledge-Based Risk Mapping Tool for Cost Estimation of International Construction Projects. Automation in Construction, 43, 144-155.

Zakaria, S.F., Zin, R.M., Mohamad, I., Balubaid, S., Mydin, S.H. \& Rahim, E.M.R. (2017). Critical Success Factors in Infrastructure Projects. Proceedings of the 3rd International Conference on Construction and Building Engineering (ICONBUILD) 2017, AIP Conference Proceeding. 